\title{
USULAN PERBAIKAN SISTEM KANBAN UNTUK OPTIMALISASI PADA PT TORISHIMA GUNA INDONESIA
}

\author{
Ira Puspita ${ }^{1}$, Ririn Regiana Dwi Satya ${ }^{2}$ \\ Program Studi Teknik Industri, Universitas Indraprasta PGRI Jakarta ${ }^{1}$ \\ irapuspita164@gmail.com ${ }^{1}$, ririn.regiana86@gmail.com ${ }^{2}$
}

Submitted June 11, 2020; Revised November 17, 2020; Accepted November 20, 2020

\begin{abstract}
Abstrak
PT Torishima Guna Indonesia merupakan salah satu perusahaan industri manufaktur yang memproduksi pompa air. Pada sistem produksi yang dijalankan dengan menggunakan hybrid yaitu dimana dapat make to stock dan make to order, namun pada produk salah satu yang menggunakan sistem make to order yaitu produk ETA-N. Produk ETA-N produk yang sangat laris, namun sering kali PT Torishima Guna Indonesia tidak memenuhi permintaan, karena adanya masalah di lantai produksi. PT Torishima Guna Indonesia sering kali terjadinya penumpuknya WIP (work in proses) pada gudang, dikarenakan spare part yang dibutuhkan tidak dikirimkan oleh supplier atau terlambat mengirimkan spare part sehingga mengakibatkan biaya penyimpanan meningkat. Dari permasalah yang telah terjadi maka hal yang dilakukan dengan menerapkan kanban diharapkan dapat menekan kelemahan-kelemahan yang terjadi pada sistem produksi di perusahaan tersebut. Kanban merupakan suatu pendekatan pull system yang mengandalkan otorisasi sebagai pengendali jumlah produksi yang akan dilakukan oleh perusahaan, dalam rangka mengendalikan bahan baku suatu produk berdasarkan peramalan permintaan konsumen. Tujuan dari penelitian ini yaitu untuk mengetahui penerapan sistem kanban pada PT Torishima Guna Indonesia, untuk mengetahui faktor terlambatnya pengiriman komponen untuk PT Torishima Guna Indonesia,untuk perancangan sistem kanban penyediaan material pada proses produksi sehingga dapat mengurangi inventori, Work in Process (WIP) pada tiap proses produksi. Pada penerapan usulan ini terbukti bahwa penurunan biaya inventori jelas terlihat yaitu sebesar $45 \%$ pada tahun 2017 dan $72 \%$ pada tahun 2018.
\end{abstract}

Kata Kunci : Kanban, Tepat Waktu dan Persediaan Biaya.

\begin{abstract}
PT Torishima Guna Indonesia is a manufacturing company that produces water pumps. In a production system that is run using a hybrid, which is where you can make to stock and make to order, but in one product that uses the make to order system, the ETA-N product. ETA-N products are very popular products, but PT Torishima Guna Indonesia often does not meet demand, due to problems on the production floor. PT Torishima Guna Indonesia often accumulates WIP (work in process) in the warehouse, because the spare parts needed are not sent by the supplier or are late in sending spare parts, resulting in increased storage costs. From the problems that have occurred, what is done by implementing kanban is expected to suppress the weaknesses that occur in the production system in the company. Kanban is a pull system approach that relies on authorization to control the amount of production to be carried out by the company, in order to control the raw materials of a product based on forecasting consumer demand. The purpose of this study is to determine the implementation of the kanban system at PT Torishima Guna Indonesia, to determine the factor of late delivery of components for PT Torishima Guna Indonesia, to design a system for providing material supply in the production process so as to reduce inventory, Work in Process (WIP) at each production process. In implementing this proposal, it is evident that the reduction in inventory costs is clearly visible, namely by $45 \%$ in 2017 and $72 \%$ in 2018.
\end{abstract}

Key Words : Kanban, Just In Time, Cost Inventory 


\section{PENDAHULUAN}

Pada berbagai perusahaan atau organisasi lain, persediaan memegang peranan yang sangat penting dalam menunjang operasi (kegiatan) dari perusahaan atau organisasi tersebut. Terlebih-lebih pada perusahaan manufacture, persediaan ada dimana-mana dan memiliki bentuk, nilai, dan tingkat kepentingan yang berbeda-beda. Masalah lain yang yang biasanya dihadapi oleh sebagian perusahaan yaitu sistem produksi yang terpusat, karena semua rencana proses produksi dibuat oleh manajemen puncak, dan kemudian baru diserahkan kepada stasiun kerja masing-masing sehingga dapat menimbulkan keterlambatan.

PT Torishima Guna Indonesia merupakan salah satu perusahaan industry manufacture yang memproduksi pompa air. Pada sistem produksi yang dijalankan dengan menggunakan hybrid yaitu dimana dapat make to stock dan make to order, namun pada produk salah satu yang menggunakan sistem make to order yaitu produk ETA-N. Produk ETA-N produk yang sangat laris, namun sering kali PT Torishima Guna Indonesia tidak memenuhi permintaan, karena adanya masalah di lantai produksi sering kali terjadinya penumpuknya WIP (work in proses) pada gudang. Berikut adalah data bahan baku pada PT Torishima Guna Indonesia:

Tabel 1. Data Spare part Produk ETA-N yang tersedia PT Torishima Guna Indonesia

\begin{tabular}{cccc}
\hline No & Bulan & $\begin{array}{c}\text { Persediaan } \\
\text { yang } \\
\text { ditetapkan }\end{array}$ & $\begin{array}{c}\text { Persediaan } \\
\text { actual }\end{array}$ \\
\hline 1 & Januari & 20 & 3 \\
2 & Febuari & 20 & 5 \\
3 & Maret & 20 & 8 \\
4 & Mei & 20 & 0 \\
5 & Juni & 20 & 5 \\
6 & Juli & 20 & 1 \\
\hline \multicolumn{4}{c}{ Sumber : PT Torishima Guna Indonesia }
\end{tabular}

Dapat dilihat dari tabel 1, bahwa persediaan bahan baku pada tahun 2018 sangat kurang terlihat bulan Januari sampai dengan Agustus kanban yang tersedia tidak sesuai dengan kanban yang telah ditetapkan sehingga terjadi nya terhentinya proses produksi khususnya di assembling, selain itu terjadinya pula menumpuknya WIP di gudang selain itu meningkatnya pula biaya penyimpanan di gudang.

Dari permasalahan yang terjadi pada perusahaan tersebut di atas maka dibuat sebuah usulan untuk perbaikan sistem kanban, dalam setiap proses produksi yang akan dikembangkan untuk mengendalikan jumlah produksi dalam setiap tahap proses produksi dengan menggunakan sistem kanban. Kanban adalah suatu alat yang digunakan untuk mencapai Just In Time (JIT) pada dunia industri khususnya industri manufacturing [1]. Terdapat 2 jenis kanban yaitu kanban yang sering digunakan adalah kanban pengambilan dan kanban perintah produksi. Kanban pengambilan menspesifikasikan jenis dan jumlah produk yang harus diambil dari proses terdahulu oleh proses berikutnya, sementara kanban perintah produksi menspesifikasikan jenis dan jumlah produk yang harus dihasilkan oleh proses terdahulu [2] . Dalam menjalankan sistem produksi Just In Time, diperlukan ketepatan dalam merencanakan jadwal produksi mulai jadwal pembelian bahan produksi, jadwal penerimaan bahan produksi, jadwal produksi, jadwal produksi hingga jadwal pengiriman produk [3].

Penerapan sistem kanban produksi dengan membuat kartu kanban yang diperlukan menghitung jumlah kanban merencanakan aliran kanban yang efisien dan sarana pendukung sistem kanban. Pada penelitian ini terdapat masalah-masalah yang terjadi yaitu terhentinya proses assembling pada lantai produksi, terjadinya menumpuknya WIP (work in proces), terjadinya peningkatan biaya penyimpanan. Untuk menghindari terjadinya permasalahanpermasalahan tersebut perlunya perencanaan pengendalikan persediaan [4]. 
Perencanaan dan pengendalian persediaan barang jadi diperusahaan ini masih terdapat beberapa masalah yaitu persediaan fisik barang digudang sisanya selalu tidak sama dengan hasil pencatatan perusahaan, pencatatan persediaan yang tidak seimbang dengan stok barang dikomputerisasi, serta banyaknya pesanan khusus yang berujung pada pembatalan sehingga terjadinya penimbunan barang jadi. [5]. Tujuan perencanaan persediaan adalah untuk menemukan jawaban atas masalah-masalah tersebut. Sehubungan dengan itu pengendalian produksi mencakup perencanaan operasi produksi, penggerakan dan penyimpanan barang. Perencanaan tersebut harus mampu menjamin tingkat pengembalian investasi maksimum atas bahan, tenaga kerja, dan lain sebagainya [6]. Setelah pada tahap proses perencanaan persediaan maka perlu juga mengetahui akan efisien produksi. Efisiensi produksi salah satu muaranya adalah penurunan biaya produksi dapat ditingkatkan melalui pengendalian sistem persediaan. [7].

\section{METODE PENELITIAN}

Penelitian ini dilakukan dengan menggunakan survey. Survei adalah suatu desain penelitian yang digunakan untuk menyediakan informasi yang berhubungan dengan prevalensi, distribusi dan hubungan antar variable dalam suatu populasi [8]. Dalam survei tersebut peneliti melakukan wawancara kepada kepala seksi bagian untuk mendapatkan data data permintaan, Bill of Material, biaya iventori, kapasitas persediaan bahan baku di gudang dan data penggunaan bahan baku kemudian menggunakan metode system kanban dalam JIT. Kanban yaitu suatu pendekatan pull system yang mengandalkan otorisasi sebagai pengendali jumlah produksi yang akan dilakukan oleh perusahaan, dalam rangka mengendalikan bahan baku suatu produk berdasarkan peramalan permintaan konsumen [9]. Selanjutnya pengolahan hasil penelitian dibagi atas 2 yaitu pengolahan berdasarkan data ketetapan yang dibuat oleh perusahaan dan pengolahan berdasarkan hasil penelitian yang akan dijadikan usulan perbaikan.

\section{HASIL DAN PEMBAHASAN}

Pada pengumpulan data dari ketetapan perusahaan yaitu Jadwal Induk Produksi (JIP) yang berguna untuk pencapaian target produksi.Jadwal produksi induk (Master Production Schedule $=$ MPS) adalah suatu jadwal produksi untuk setiap jenis atau setiap macam barang yang didasarkan pada rencana produksi semesta yang sudah disusun untuk barang tersebut [10]. Hasil JIP yang diperoleh merupakan hasil dari permintaan actual dengan ketetapan. Berikut adalah hasil data jadwal induk yang diperoleh:

Tabel 2. Data Spare part Produk ETA-N yang tersedia PT Torishima Guna Indonesia

\begin{tabular}{cccccc}
\hline No & Bulan & $\begin{array}{c}\text { Permintaan } \\
\text { Aktual }\end{array}$ & $\begin{array}{c}\text { Persediaan } \\
\text { yang } \\
\text { ditetapkan }\end{array}$ & $\begin{array}{c}\text { JIP } \\
\text { per } \\
\text { bulan }\end{array}$ & $\begin{array}{c}\text { JIP Per } \\
\text { Minggu }\end{array}$ \\
\hline 1 & Januari & 201 & 20 & 221 & 55 \\
2 & Februari & 185 & 20 & 205 & 51 \\
3 & Maret & 204 & 20 & 224 & 56 \\
4 & April & 160 & 20 & 180 & 45 \\
5 & Mei & 142 & 20 & 162 & 41 \\
6 & Juni & 91 & 20 & 111 & 28 \\
7 & Juli & 131 & 20 & 151 & 38 \\
8 & Agustus & 226 & 20 & 246 & 62 \\
9 & September & 136 & 20 & 156 & 39 \\
10 & Oktober & 189 & 20 & 209 & 52 \\
11 & November & 249 & 20 & 269 & 67 \\
12 & Desember & 172 & 20 & 192 & 48 \\
\hline & & \multicolumn{3}{c}{ Sumber : Pengolahan Data }
\end{tabular}

Berikut merupakan hasil yang diperoleh dari pengolahan data perusahaan.

JIP perbulan $=$ Permintaan Aktual + Persediaan

Maka, JIP Januari $=201+20=221$

$\mathrm{JIP}_{\text {minggu }}=\mathrm{JIP}_{\text {perbulan }} / 4$ minggu

Maka, JIP minggu $=221 / 4=55$

Kanban merupakan alat produksi yang berfungsi sebagai informasi jumlah komponen yang dipesan. Berikut adalah 
jumlah kanban pemasok pada PT Torishima Guna Indonesia:

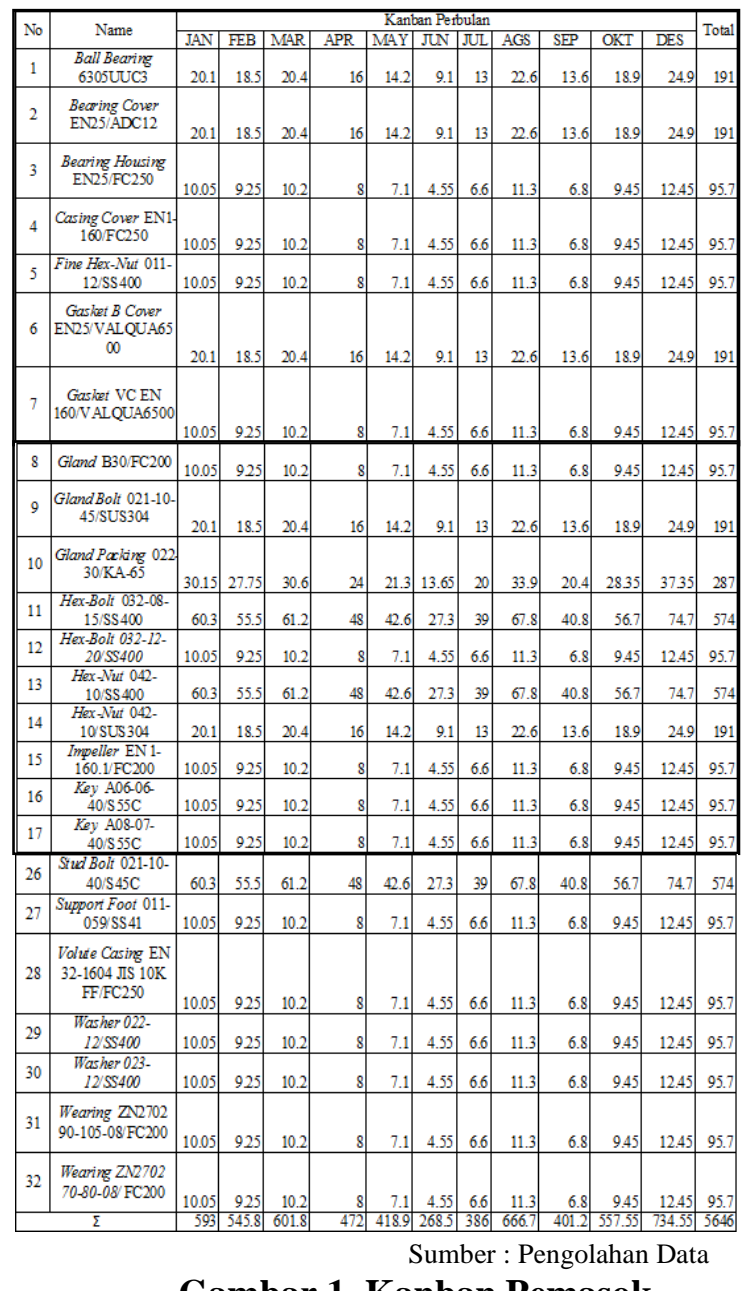

Gambar 1. Kanban Pemasok

Dari data diatas diperoleh permintaan aktual atau persediaan yang ditetapkan yaitu Kanban Jan =Permintaan actual/ Persediaan $=201 / 20=10$ kartu kanban pemasok per masing-masing sparepart atau dengan jumlah dalam bulan januari untuk semua spare part sebesar 593 kartu kanban pemasok. Dari hasil yang diperoleh sangatlah memakan biaya besar sebab dalam setiap pemesan atau lot sizenya tidak diperhitungkan sehingga sangat merugikan perusahan atau terjadinya pembengkakan biaya inventori. Lot size setiap pemesanan sebesar 10 spare part sehingga yang diperlukan dalam bulan januari sebesar 50 kartu kanban pemasok untuk jumlah seluruh spare part yang dibutuhkan.
Pada pengolahan data usulan perbaikan dilakukan forecasting. Pada PT Torishima Guna Indonesia forecasting belum diterapkan sehingga banyak terjadi kendala terkait masalah dalam mengatasi fluktuasi permintaan jumlah produk. Berikut adalah hasil forecasting yang didapatkan:

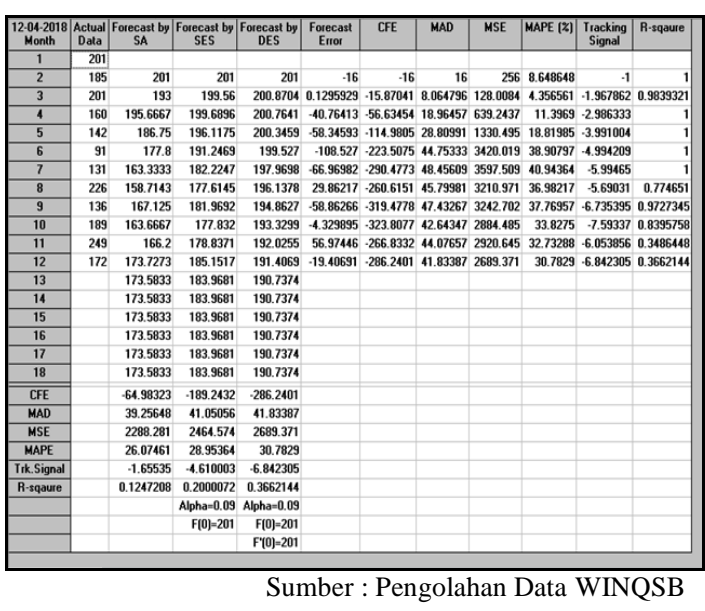

Gambar 2. Forecasting Tahun 2017

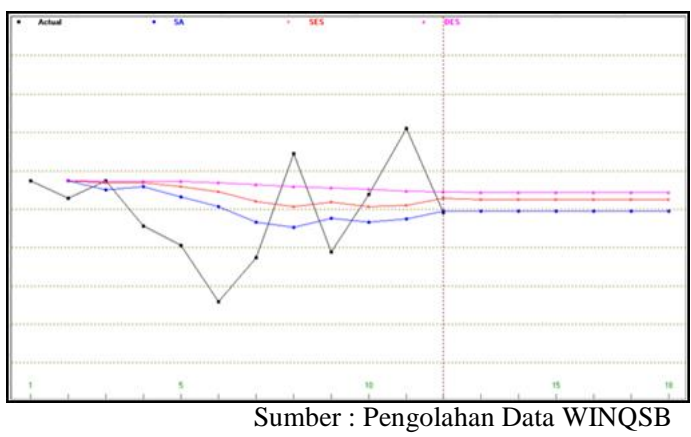

Gambar 3. Grafik Forecasting

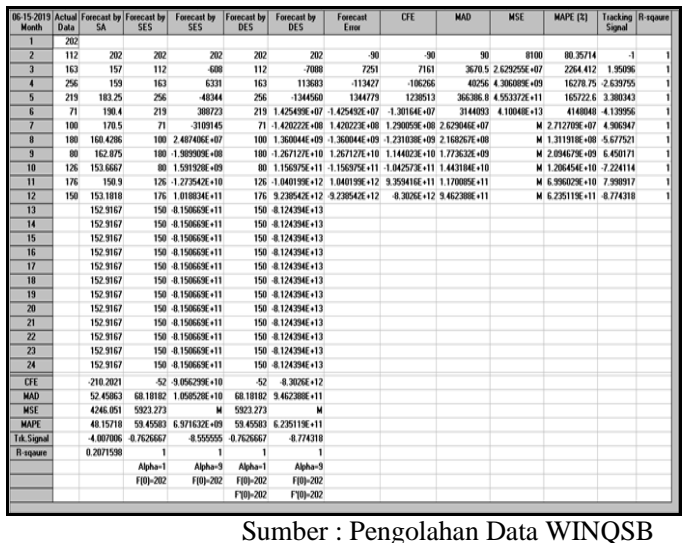

Gambar 4. Forecasting Tahun 2018 


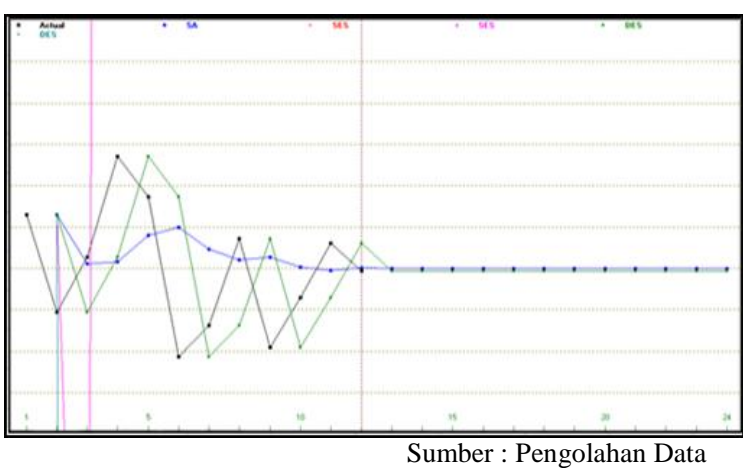

Gambar 5. Grafik Forecasting Tahun 2018

Hasil diatas merupakan pengolahan forecasting menggunakan software WINQSB dengan menggunakan metode Single Moving Average, single eksponential smoothing dan Double Eksponential Smoothing. Berikut adalah uraian hasil pengolahan tahun 2017 dan 2018:

Tabel 3. Hasil Pengolahan tahun 2017 dan 2018

\begin{tabular}{|c|c|c|c|}
\hline Tahun & MAD & Keterangan & $\begin{array}{l}\text { Metode } \\
\text { terbaik }\end{array}$ \\
\hline \multirow{3}{*}{2017} & 39,25 & $\begin{array}{c}\text { Menggunakan } \\
\text { metode SA }\end{array}$ & \\
\hline & 41,05 & $\begin{array}{c}\text { Menggunakan single } \\
\text { eksponential } \\
\text { smoothing }\end{array}$ & SA \\
\hline & 41,83 & $\begin{array}{c}\text { Menggunakan } \\
\text { Double eksponential } \\
\text { smoothing }\end{array}$ & \\
\hline \multirow{3}{*}{2018} & 52,14 & $\begin{array}{c}\text { Menggunakan } \\
\text { metode SA }\end{array}$ & \\
\hline & 59,55 & $\begin{array}{c}\text { Menggunakan single } \\
\text { eksponential } \\
\text { smoothing }\end{array}$ & SA \\
\hline & 59,55 & $\begin{array}{c}\text { Menggunakan } \\
\text { Double eksponential } \\
\text { smoothing }\end{array}$ & \\
\hline
\end{tabular}

Berikut adalah hasil kanban produksi dengan menggunakan software POMQM:

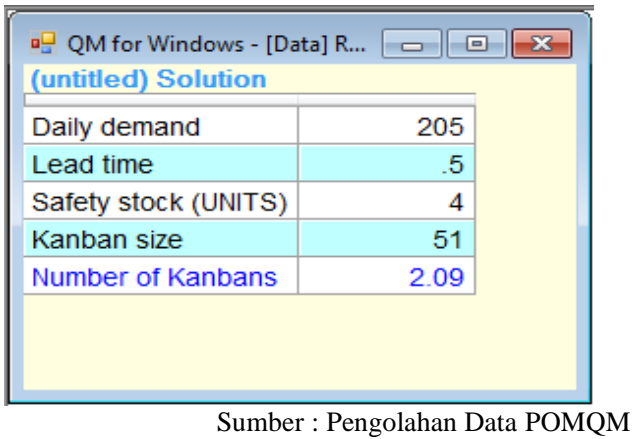

Gambar 6. Hasil Kanban Produksi

Berdasarkan gambar diatas menjelaskan bahwa untuk kanban produksi pada bulan januari didapatkan hasil numbers of kanbans sebesar 2,61 atau dapat dikatakan nomor kanban sebesar 3. Berikut adalah pengolahan kanban pemasok:

\begin{tabular}{|c|c|c|c|c|c|c|}
\hline No & Bulan & $\begin{array}{c}\text { Permintaan } \\
\text { Peramalan }\end{array}$ & $\begin{array}{c}\text { Lead time to } \\
\text { supplier }\end{array}$ & $\begin{array}{c}\text { Lost Spare } \\
\text { Part }\end{array}$ & Lot Size & $\begin{array}{c}\text { Kanban } \\
\text { Supplier }\end{array}$ \\
\hline 1 & January & 201 & 0.5 & 4 & 10 & 50 \\
\hline 2 & February & 193 & 0.5 & 4 & 10 & 45 \\
\hline 3 & Maret & 187 & 0.5 & 4 & 10 & 47 \\
\hline 4 & April & 164 & 0.5 & 3 & 10 & 34 \\
\hline 5 & Mei & 159 & 0.5 & 3 & 10 & 31 \\
\hline 6 & Juni & 168 & 0.5 & 2 & 10 & 24 \\
\hline 7 & Juli & 164 & 0.5 & 3 & 10 & 30 \\
\hline 8 & Agustus & 167 & 0.5 & 5 & 10 & 46 \\
\hline 9 & September & 174 & 0.5 & 3 & 10 & 32 \\
\hline 10 & Oktober & 174 & 0.5 & 4 & 10 & 42 \\
\hline 11 & November & 174 & 0.5 & 5 & 10 & 52 \\
\hline 12 & Desember & 174 & 0.5 & 3 & 10 & 39 \\
\hline & 2 & 2099 & 6 & 42 & 120 & 472 \\
\hline \hline
\end{tabular}

Gambar 7. Hasil Kanban Pemasok Tahun 2017 


\begin{tabular}{|c|c|r|c|c|c|c|}
\hline No & Bulan & $\begin{array}{c}\text { Permintaan } \\
\text { Peramalan }\end{array}$ & $\begin{array}{c}\text { Lead time to } \\
\text { supplier }\end{array}$ & $\begin{array}{c}\text { Lost Spare } \\
\text { Part }\end{array}$ & Lot Size & $\begin{array}{c}\text { Kanban } \\
\text { Supplier }\end{array}$ \\
\hline 1 & January & 202 & 0.5 & 4 & 10 & 51 \\
\hline 2 & February & 157 & 0.5 & 2 & 10 & 25 \\
\hline 3 & Maret & 159 & 0.5 & 3 & 10 & 34 \\
\hline 4 & April & 184 & 0.5 & 5 & 10 & 56 \\
\hline 5 & Mei & 191 & 0.5 & 4 & 10 & 51 \\
\hline 6 & Juni & 171 & 0.5 & 1 & 10 & 21 \\
\hline 7 & Juli & 161 & 0.5 & 2 & 10 & 24 \\
\hline 8 & Agustus & 163 & 0.5 & 4 & 10 & 37 \\
\hline 9 & September & 154 & 0.5 & 2 & 10 & 20 \\
\hline 10 & Oktober & 151 & 0.5 & 3 & 10 & 27 \\
\hline 11 & November & 154 & 0.5 & 4 & 10 & 35 \\
\hline 12 & Desember & 153 & 0.5 & 3 & 10 & 31 \\
\hline & 5 & 2000 & 6 & 37 & 120 & 412 \\
\hline
\end{tabular}

\section{Gambar 8. Hasil Kanban Pemasok Tahun 2018}

Kemudian berikut merupakan biaya inventory yang ada pada PT Thorisima Guna Indonesia:

Tabel 4. Biaya Inventory

\begin{tabular}{cccc}
\hline Stock & $\begin{array}{c}\text { Avg 2017 } \\
\text { (Rp) }\end{array}$ & Avg 2018 (Rp) & Presentase \\
\hline Awal & 5.111 .442 .390 & 10.805 .453 .373 & $111 \%$ \\
Usulan & 2.835 .534 .262 & 3.070 .896 .290 & $8 \%$ \\
Presentase & $45 \%$ & $72 \%$ & \\
\hline \multicolumn{4}{c}{ Sumber : Pengolahan Data }
\end{tabular}

Dan dari hasil yang diperoleh setelah pengolahan data terjadi penurunan biaya inventory yang sangat dratis dapat dilihat dari hasil EOQ pada tahun 2017 sebesar 7827 unit dan EOQ pada tahun 2018 sebesar 7417 unit. Sedangkan hasil TIC (biaya inventory) pada tahun 2017 sebesar Rp 2.835.534.262,- dan pada tahun 2018 yaitu sebesar Rp 3.070.896.291,- dengan presentase penurunan sebesar tahun 2017 sebesar $45 \%$ dan 2018 sebesar $72 \%$.

\section{SIMPULAN}

Berdasarkan pengamatan dan pengolahan data yang telah dilakukan adalah sebagai berikut pada PT Torishima Guna Indonesia menumpuknya work in process dan terhentinya proses assembling membuat biaya inventori membengkak besar. Kenaikan biaya inventory sebesar $111 \%$ dari tahun ke 2017-2018. Oleh sebab itu dengan adanya usulan system kanban terjadi penurunan biaya inventory yang sangat dratis yaitu tahun ke 20172018 sebesar 8\%, sehingga dapat meminimumkan biaya inventory yang jauh lebih baik dari yang sebelumnya.

\section{DAFTAR PUSTAKA}

[1] W. Anggrait, "Usulan Perbaikan Sistem Kanban Untuk Mengurangi Penumpukan Work In Process dan Lead Time Produksi Pada Lantai Produksi Bagian Medium Prismatic Machines Di PT . Dirgantara Indonesia," vol. 2, no. 1, pp. 1-11, 2013, doi: http://kin.perpusnas.go.id/DisplayDa ta.aspx?pId=100306\&pRegionCode $=$ TELUNI\&pClientId $=116$.

[2] L. Q. BING, Implementation of Ordering Kanban for Supplier At, 1st ed., no. June. Malaysia, 2012.

B. Wirawan, "Penerapan Just In Time Pada Perancangan Model Penjadwalan Produksi dengan Sistem Tarik," vol. XVI, no. 1, 2018, doi: https://ejournal.bsi.ac.id/ejurnal/inde x.php/perspektif/article/view/3040.

[4] N. Apriyani and A. Muhsin, "Analisis Pengendalian Persediaan Bahan Baku Dengan Metode Economic Order Quantity Dan Kanban Pada Pt Adyawinsa Stamping Industries," Opsi, vol. 10, no. 2, p. 128, 2017, doi: 10.31315/opsi.v10i2.2108.

[5] H. Ponda et al., "Analisis Jumlah Kanban Pada Proses Produksi Support Assy Brake Pedal Part No . Xxxx-Xxxx Di Departemen Welding Pt. Ntc," vol. 1, no. 2, pp. 8-15, 2012, doi: http://dx.doi.org/10.31000/jt.v9i2. 
STRING (Satuan Tulisan Riset dan Inovasi Teknologi)

Vol. 5 No. 2 Desember 2020

[6] S. Simulga, Perencanaan dan Pengendalian Produksi, 1st ed. Yogyakarta: Graha Ilmu, 2009.

[7] D. Bangun, Manajemen Perusahaan, 1st ed. Sidoarjo: Dian Samudra, 2010.

[8] P. Praktis, ILMU KEPERAWATAN Pendekatan Praktis, 4th ed. Jakarta: Salemba Medika, 2015.

[9] H. Thadeus and T. Octavia, "Penerapan Kanban pada Sistem Inventori PT FSCM Manufacturing
p-ISSN: $2527-9661$

e-ISSN: 2549 - 2837

Indonesia," vol. 6, no. 2, pp. 115122, 2018, doi: http://publication.petra.ac.id/index.p hp/teknik-industri/article/view/7345.

[10] R. Supriyadi, "Penjadwalan Produksi IKS-Filler Pada Proses Ground Calcium Carbonate Menggunakan Metode MPS Di Perusahaan Kertas," vol. Vol. 20, N, pp. 157-164, 2015, doi: 10.22441/sinergi.2016.2.010. 